\title{
Piper sarmentosum attenuates dexamethasone-induced hypertension by stimulating endothelial nitric oxide synthase
}

\author{
Azizah UGUSMAN 1* (D), Noor Fazilah MD FADZE 1 (D), Adila A HAMID 1 (D), Zanariyah ASMAWI 1 (D) \\ Amilia AMINUDDIN 1 iD \\ 1 Department of Physiology, Faculty of Medicine, Universiti Kebangsaan Malaysia Medical Centre, Kuala Lumpur, \\ Malaysia. \\ * Corresponding Author. E-mail: dr.azizah@ppukm.ukm.edu.my (A.U.); Tel. +603-9145 8614.
}

Received: 12 September 2019 / Revised: 09 December 2019/ Accepted: 23 December 2019

\begin{abstract}
Reduced endothelial nitric oxide (NO) synthesized by endothelial nitric oxide synthase (eNOS) in the vasculature is a feature of endothelial dysfunction. Dexamethasone causes secondary hypertension by inhibiting eNOS activity. Piper sarmentosum is an herb with anti-hypertensive effect. The aim of this study was to evaluate the antihypertensive effect of aqueous extract of $P$. sarmentosum (AEPS) in dexamethasone (Dex)-induced hypertensive rats. A total of 30 male Sprague Dawley rats were divided into five groups including control, AEPS ( $500 \mathrm{mg} / \mathrm{kg} / \mathrm{day}$, orally), Dex $(20 \mu \mathrm{g} / \mathrm{kg} /$ day, subcutaneously), Dex $(20 \mu \mathrm{g} / \mathrm{kg} /$ day $)+$ AEPS $(500 \mathrm{mg} / \mathrm{kg} /$ day $)$ and Dex $(20 \mu \mathrm{g} / \mathrm{kg} / \mathrm{day})+$ captopril $(40 \mathrm{mg} / \mathrm{kg} /$ day, orally). Blood pressure was measured using tail-cuff method at baseline and fortnightly thereafter. The rats were sacrificed and the serum was collected to quantify the amount of NO after 28 days of treatment. Aortic samples were homogenized for measurement of eNOS mRNA expression, protein level and activity. Treatment of Dex-induced hypertensive rats with AEPS lowered systolic blood pressure $(P<0.001)$ and diastolic blood pressure $(P<0.01)$, increased eNOS mRNA expression $(P<0.01)$, eNOS protein $(P<0.01)$, eNOS activity $(P<0.05)$ and NO level $(P<0.05)$. In conclusion, AEPS reduces the blood pressure of Dex-induced hypertensive rats as it shows positive effects on eNOS and NO production.
\end{abstract}

KEYWORDS: Dexamethasone; endothelial nitric oxide synthase; hypertension; nitric oxide; Piper sarmentosum.

\section{INTRODUCTION}

Hypertension is a risk factor of cardiovascular diseases that leads to some serious complications such as stroke and ischemic heart disease [1]. Globally, 1.39 billion adults aged 20 years and above have been reported with hypertension in 2010 [2]. The prevalence of elevated systolic blood pressure (SBP) in adult population had been increasing since 1990 until 2015. It was estimated that 874 million adults had SBP of 140 $\mathrm{mm} \mathrm{Hg}$ or higher in 2015 [1].

Nitric oxide $(\mathrm{NO})$ is a potent vasodilator that helps to reduce total peripheral resistance and blood pressure [3]. Majority of endothelial NO is produced by endothelial nitric oxide synthase (eNOS) [4]. Reduction of NO is a cardinal feature of endothelial dysfunction which contributes to hypertension [4]. Dexamethasone (Dex) is a synthetic glucocorticoid that has been widely used to treat various diseases such as autoimmune diseases and asthma [5, 6]. Hypertension is a common side effect of chronic Dex usage [7]. Dex administration could induce hypertension via multiple mechanisms such as induction of oxidative stress, downregulation of cationic amino acid transporter-1, downregulation of eNOS and reduction of NO [8].

Piper sarmentosum is a medicinal herb that has been used traditionally to treat diabetes and pleurisy in Southeast Asia [9, 10]. Other studies have shown that P. sarmentosum has antioxidant [11, 12], antiatherosclerosis [13] and anti-diabetic [14] activities. Toxicity studies involving 28 days oral administration of aqueous extract of $P$. sarmentosum up to $2000 \mathrm{mg} / \mathrm{kg}$ of body weight in Sprague Dawley rats reported no adverse effect [11]. In addition, $P$. sarmentosum has been shown to reduce blood pressure in spontaneously hypertensive rats by increasing NO production [12]. P. sarmentosum could also enhance NO production by stimulating eNOS activity in oxidative stress-induced human umbilical vein endothelial cells (HUVEC) [15].

How to cite this article: : Ugusman A, Md Fadze N F, A Hamid A, Asmawi Z, Aminuddin A. Piper sarmentosum attenuates dexamethasoneinduced hypertension by stimulating endothelial nitric oxide synthase. J Res Pharm. 2020; 24(1): 150-158. 
However, there is no study that evaluates the anti-hypertensive effect of $P$. sarmentosum in Dex-induced hypertensive rat model. Therefore, this study was aimed to determine the effects of standardized aqueous extract of $P$. sarmentosum leaf (AEPS) on blood pressure, eNOS level and NO production in Dex-induced hypertensive rats.

\section{RESULTS}

\subsection{Effects of AEPS on blood pressure}

Table 1 shows the blood pressure readings at baseline (day-0), day-14 and day-28 post treatment. At baseline, there was no significant difference among the groups in all the blood pressure parameters including systolic blood pressure (SBP), diastolic blood pressure (DBP) and mean arterial pressure (MAP). Rats treated with AEPS did not show any significant changes in the blood pressure compared to the control throughout the experiment. On day 14 and 28 post-treatment, induction with Dex increased the SBP $(P<0.001), \operatorname{DBP}(P<$ $0.001)$ and MAP $(P<0.001)$ compared to control. Treatment of Dex-induced hypertensive rats with AEPS successfully reduced the SBP $(P<0.001)$, DBP $(P<0.01)$ and MAP $(P<0.001)$ and these effects were comparable with captopril.

Table 1. Blood pressure readings at baseline, day 14 and day 28 of post-treatment.

\begin{tabular}{|c|c|c|c|c|c|c|c|c|c|}
\hline \multirow{2}{*}{ Group } & \multicolumn{3}{|c|}{ SBP (mmHg) } & \multicolumn{3}{|c|}{ DBP (mmHg) } & \multicolumn{3}{|c|}{ MAP (mmHg) } \\
\hline & 0 & 14 & 28 & 0 & 14 & 28 & 0 & 14 & 28 \\
\hline \multirow{2}{*}{ Control } & $112 \pm$ & $110 \pm$ & $105 \pm$ & $80 \pm$ & $82 \pm$ & $77 \pm$ & $91 \pm$ & $92 \pm$ & $87 \pm$ \\
\hline & 1.6 & 3.7 & 3.8 & 6.7 & 4.0 & 2.5 & 5.3 & 3.3 & 2.5 \\
\hline \multirow{2}{*}{ AEPS } & $115 \pm$ & $115 \pm$ & $105 \pm$ & $81 \pm$ & $77 \pm$ & $69 \pm$ & $93 \pm$ & $90 \pm$ & $85 \pm$ \\
\hline & 3.6 & 3.9 & 3.3 & 2.9 & 5.3 & 4.5 & 2.9 & 3.7 & 3.5 \\
\hline \multirow{2}{*}{ Dex } & $108 \pm$ & $136 \pm$ & $146 \pm$ & $74 \pm$ & $105 \pm$ & $104 \pm$ & $85 \pm$ & $114 \pm$ & $118 \pm$ \\
\hline & 2.5 & $2.0^{* * *}$ & $2.7^{\star \star *}$ & 4.1 & $2.5^{* *}$ & $3.1^{* * *}$ & 3.1 & $2.2^{* * *}$ & $2.5^{* * *}$ \\
\hline \multirow{2}{*}{ Dex + AEPS } & $108 \pm$ & $111 \pm$ & $107 \pm$ & $82 \pm$ & $82 \pm$ & $79 \pm$ & $91 \pm$ & $92 \pm$ & $88 \pm$ \\
\hline & 3.6 & $2.8^{\# \# \#}$ & $2.9 \# \# \#$ & 3.8 & $5.1^{\# \#}$ & $1.7^{\# \#}$ & 3.2 & 3.7\#\#\# & $1.4^{\# \# \#}$ \\
\hline \multirow{2}{*}{ Dex + Capt } & $117 \pm$ & $115 \pm$ & $105 \pm$ & $79 \pm$ & $83 \pm$ & $78 \pm$ & $91 \pm$ & $94 \pm$ & $87 \pm$ \\
\hline & 3.5 & $3.2^{\# \# \#}$ & $3.3^{\# \# \#}$ & 3.2 & $5.0^{\# \#}$ & $5.6^{\# \#}$ & 3.1 & $3.6^{\# \# \#}$ & 4.7\#\#\# \\
\hline
\end{tabular}

SBP: systolic blood pressure; DBP: diastolic blood pressure; MAP: mean arterial pressure; AEPS: aqueous extract of Piper sarmentosum; Dex: dexamethasone; Capt: captopril). Data are expressed as mean $\pm \mathrm{SEM} ; n=$ 6 in each group; ${ }^{* *} P<0.01$ and ${ }^{* * *} P<0.001$ compared to control within the same day; $\# \# P<0.01$ and $\# \# \#<$ 0.001 compared to Dex group within the same day.

\subsection{Effects of AEPS on eNOS mRNA expression}

AEPS treatment upregulated eNOS mRNA expression by 1.9-fold compared to control $(P<0.01)$ (Figure 1). Meanwhile, Dex downregulated eNOS mRNA expression by 0.5 -fold compared to control $(P<0.01)$. Treatment of Dex-induced rats with AEPS and captopril upregulated eNOS mRNA expression by 1.4-fold $(P$ $<0.01)$ and 1.7-fold $(P<0.001)$ respectively compared to Dex-induced group. However, there was no significant difference in eNOS mRNA expression observed between Dex + AEPS and Dex + captopril group.

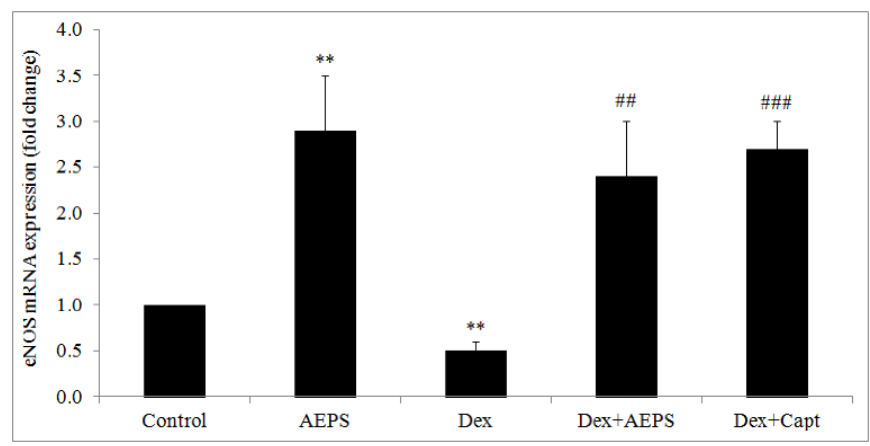

Figure 1. Effect of AEPS on eNOS mRNA expression in dexamethasone-induced hypertensive rats (AEPS: aqueous extractof $P$. Sarmentosum; Dex: Dexamethasone; Capt: captopril; eNOS: endothelial nitric oxide synthase). Data were expressed as mean \pm SEM $(n=6)$. ${ }^{* *} P<0.01$ compared with control; \#\#P<0.01 and $\# \#$ \# $<0.001$ compared with Dex group. 


\subsection{Effects of AEPS on eNOS protein level}

Administration of AEPS increased eNOS protein level (110.17 $\pm 18.98 \mathrm{pg} / \mathrm{mg}$ protein) compared to control $(28.50 \pm 3.64 \mathrm{pg} / \mathrm{mg}$ protein) $(P<0.01)$ (Figure 2). Induction with Dex caused a reduction in eNOS protein level $(10.17 \pm 1.54 \mathrm{pg} / \mathrm{mg}$ protein; $P<0.01)$. Moreover, treatment of Dex-induced hypertensive rats with AEPS increased eNOS protein level $(40.17 \pm 9.51 \mathrm{pg} / \mathrm{mg}$ protein; $P<0.01)$. Besides, Dex + captopril group also showed an increase in eNOS protein level $(46.67 \pm 7.37 \mathrm{pg} / \mathrm{mg}$ protein; $P<0.01)$. There was no significant difference shown in eNOS protein level between Dex + AEPS and Dex + captopril group.

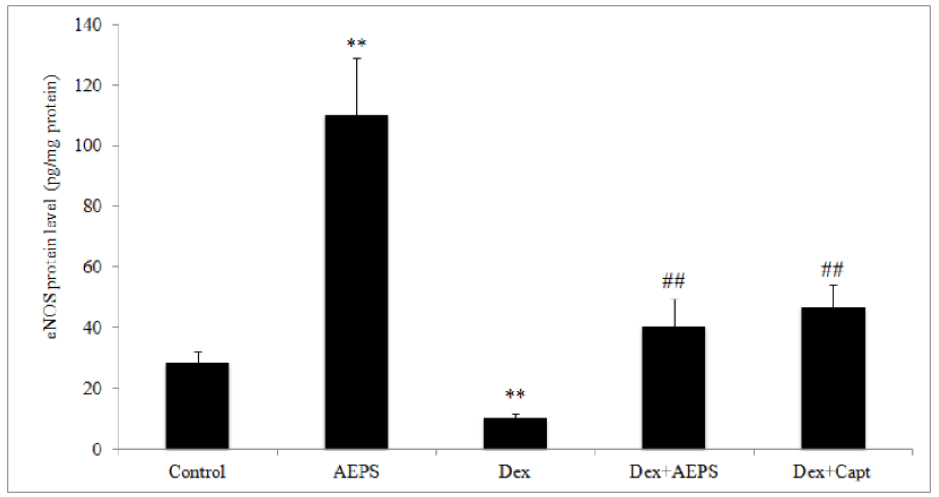

Figure 2. Effect of AEPS on eNOS protein level in dexamethasone-induced hypertensive rats. Data were expressed as mean \pm SEM $(n=6)$. ${ }^{*} P<0.01$ compared with control; $\# P<0.01$ compared with Dex group. AEPS: aqueous extractof $P$. sarmentosum; Dex: dexamethasone; Capt: captopril; eNOS: endothelial nitric oxide synthase.

\subsection{Effects of AEPS on eNOS activity}

Treatment with AEPS increased eNOS activity $(2.1 \pm 0.231 \mu \mathrm{M}$ nitrite $/ \mathrm{min} / \mathrm{mg}$ protein $)$ compared to control $(1.4 \pm 0.103$ nitrite $/ \mathrm{min} / \mathrm{mg}$ protein) $(P<0.05)$ (Figure 3$)$. Dex inhibited eNOS activity $(1.1 \pm 0.073 \mu \mathrm{M}$ nitrite $/ \mathrm{min} / \mathrm{mg}$ protein) compared with control $(P<0.05)$. AEPS was able to stimulate eNOS activity in Dexinduced hypertensive rats $(1.4 \pm 0.109 \mu \mathrm{M}$ nitrite $/ \mathrm{min} / \mathrm{mg}$ protein; $P<0.05)$. Captopril also increased eNOS activity in Dex-induced hypertensive rats $(1.4 \pm 0.201 \mu \mathrm{M}$ nitrite $/ \mathrm{min} / \mathrm{mg}$ protein; $P<0.05)$. There was no significant difference in eNOS activity between Dex + AEPS and Dex + captopril group.

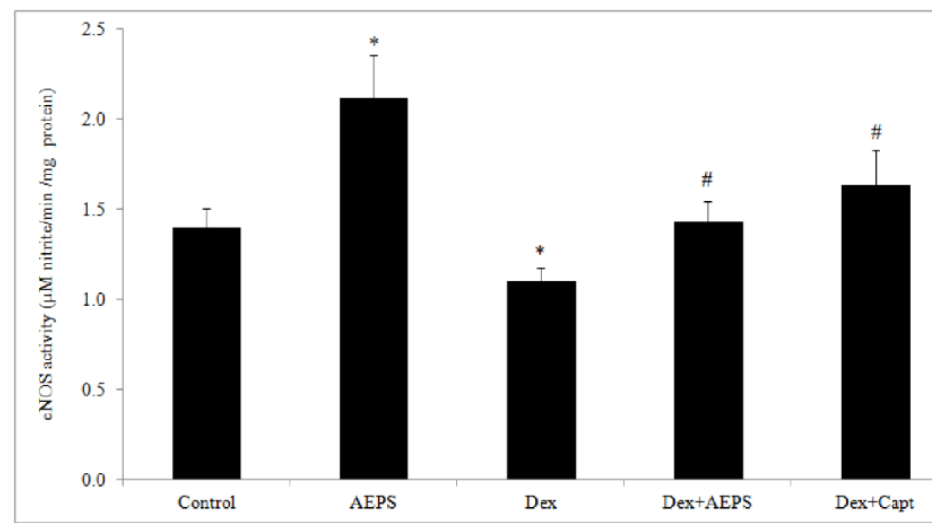

Figure 3. Effect of AEPS on eNOS activity in dexamethasone-induced hypertensive rats. Data are expressed as mean $\pm \operatorname{SEM}(n=6)$. ${ }^{*} P<0.05$ compared with control; $\# P<0.05$ compared with Dex group. AEPS: aqueous extractof P. sarmentosum; Dex: dexamethasone; Capt: captopril; eNOS: endothelial nitric oxide synthase.

\subsection{Effects of AEPS on NO Level}

NO level in rats treated with AEPS $(78.6 \pm 8.01 \mu \mathrm{M})$ was increased compared with control $(52.8 \pm 7.03$ $\mu \mathrm{M})(P<0.05)$ (Figure 4). Serum NO level was decreased in rats induced with Dex $(31.0 \pm 5.18 \mu \mathrm{M})$ compared to control $(P<0.05)$. AEPS treatment in Dex-induced hypertensive rats resulted in increased NO (56.8 \pm 6.22 $\mu \mathrm{M}, P<0.05)$. Captopril also increased serum NO level in Dex-induced hypertensive rats $(56.1 \pm 6.14 \mu \mathrm{M}, P<$ 
0.05). However, there was no significant difference in NO level between Dex + AEPS and Dex + captopril group.

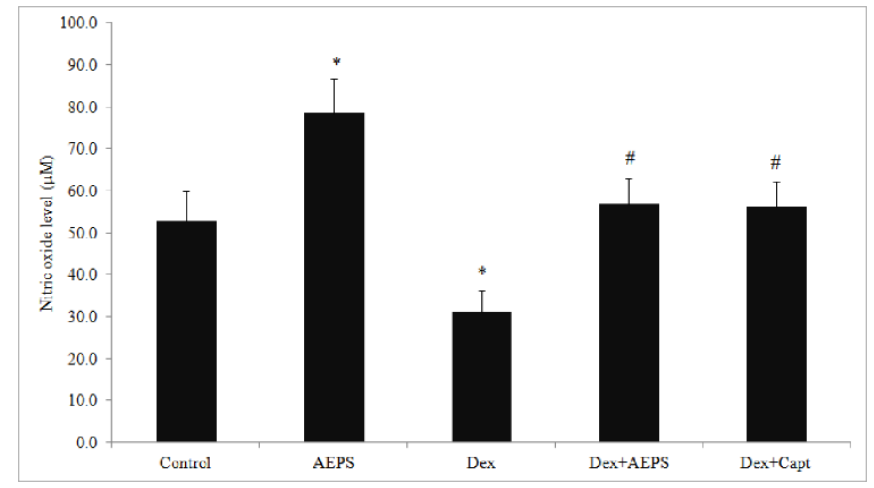

Figure 4. Effect of AEPS on nitric oxide level in dexamethasone-induced hypertensive rats. Data were expressed as mean \pm SEM $(n=6)$. ${ }^{*} P<0.05$ compared with the control; $\# P<0.05$ compared with the Dex group. AEPS: aqueous extractof $P$. sarmentosum; Dex: dexamethasone; Capt: captopril; eNOS: endothelial nitric oxide synthase.

\section{DISCUSSION}

Lack of endothelial NO is a feature of endothelial dysfunction that is involved in the pathogenesis of hypertension [4]. Fortnightly blood pressure measurements following induction with $20 \mu \mathrm{g} / \mathrm{kg} / \mathrm{day}$ dexamethasone indicated that the rats were in hypertensive state. Previous study has found that subcutaneous injection of dexamethasone at similar dose has increased SBP and DBP on day 5 post-induction [16]. The results also showed that Dex-induced hypertensive rats had lower expression of eNOS mRNA, protein and activity as well as lower serum NO level. Current findings were in concurrent with previous studies whereby Dexinduced hypertensive rats had lower expression of eNOS mRNA, protein and activity [17]. Downregulation of eNOS mRNA expression had caused less eNOS protein to be synthesized and subsequently led to decreased eNOS activity and NO production. Dex reduces NO production through several mechanisms including reduction of eNOS substrate L-arginine and reduction in the synthesis of eNOS cofactor such as tetrahydrobiopterin $\left(\mathrm{BH}_{4}\right)$ by GTP cyclohydrolase [18]. Lack of $\mathrm{BH}_{4}$ leads to eNOS uncoupling and results in increased superoxide production and reduced NO bioavailability [18].

AEPS was effective in reducing the blood pressure of Dex-induced hypertensive rats. Treatment of Dexinduced hypertensive rats with AEPS enhanced eNOS mRNA level, protein level and activity as well as NO level. Upregulation of eNOS mRNA expression had caused more eNOS protein to be synthesized and led to increased eNOS activity and NO production. In cultured HUVEC, AEPS stimulated endothelial cells to produce NO by increasing eNOS mRNA expression, protein level and activity [15]. Besides, AEPS has antioxidant activity which could contribute to the increased bioavailability of NO [12]. Moreover, antioxidant protects NO from oxidative degradation by reactive oxygen species and therefore preserves NO bioavailability [18]. In spontaneously hypertensive rats, AEPS could lower the blood pressure by reducing oxidative stress and increasing NO level [12]. Therefore, the blood pressure lowering effect of AEPS in this study might be arisen from its antioxidant effect, which needs to be clarified with future studies.

Standardized AEPS contains the flavonoids rutin and vitexin [19]. Previous study had shown that rutin increased NO production by inducing eNOS mRNA expression, protein synthesis and activity in HUVEC [19]. Oral administration of rutin decreased SBP and DBP of sodium chloride-induced hypertensive rats [20]. In addition, vitexin lowered the blood pressure and total cholesterol of NG-nitro-L-arginine methyl ester (LNAME)-induced hypertensive mice. Thus, the anti-hypertensive effect of AEPS may be due to the actions of the aforementioned flavonoids.

In this study, the anti-hypertensive effect of AEPS was compared with captopril, an angiotensin converting enzyme (ACE) inhibitor. Treatment of Dex-induced hypertensive rats with captopril had reduced the blood pressure and increased the eNOS mRNA expression, protein level and activity as well as NO level. Captopril had also been reported to give a positive impact on the production of NO in previous studies. Treatment with captopril decreased the blood pressure by increasing the expression of eNOS in aortic tissues and restoring the plasma NO level in L-NAME-induced hypertensive rats [21]. There was no significant difference observed between the effects of AEPS and captopril on the blood pressure, eNOS level and serum 
NO in Dex-induced hypertensive rats. This shows that AEPS has similar anti-hypertensive effect with captopril in Dex-induced hypertensive rats.

This experiment was an in vivo animal study that investigated some fundamental anti-hypertensive effects of AEPS. The data suggested that AEPS could reduce Dex-induced hypertension by increasing NO. However, further pharmacological evaluations are required to identify and isolate the anti-hypertensive compounds in AEPS as well as elucidating their mechanisms of action. In addition, clinical trials with large sample size and excellent methodological quality will also be needed to provide a confirmed conclusion of the effectiveness and safety of AEPS as a treatment for hypertension in humans.

\section{CONCLUSION}

The present study shows that AEPS reduces blood pressure in Dex-induced hypertensive rats by stimulating eNOS activity and NO production. Therefore, AEPS has the potential to be developed as an anti-hypertensive agent in the future. Further studies are needed to corroborate these findings.

\section{MATERIALS AND METHODS}

\subsection{Preparation of standardized aqueous extract of $P$. sarmentosum (AEPS)}

Leaves of P. sarmentosum were purchased from Herbagus Sdn. Bhd, Penang, Malaysia and was authenticated by a plant taxonomist from Faculty of Science and Technology, Universiti Kebangsaan Malaysia (voucher specimen number: UKMB40240). AEPS was prepared and standardized to contain $0.52 \%(\mathrm{w} / \mathrm{w})$ vitexin and $0.76 \%(\mathrm{w} / \mathrm{w})$ rutin as described previously [22]. Fresh leaves of $P$. sarmentosum were cleaned with tap water and oven-dried at $40^{\circ} \mathrm{C}$ for four days. Dried $P$. sarmentosum leaves were grinded and mixed with distilled water $(1: 10, \mathrm{w} / \mathrm{v})$ in a high-speed mixer. Then, the mixture was boiled at $80^{\circ} \mathrm{C}$ for three hours. AEPS was filtered and concentrated repeatedly, followed by freeze-drying. The powdered form of AEPS was then stored at $4{ }^{\circ} \mathrm{C}$. High performance liquid chromatography (HPLC) analysis was carried out using HPLC system (Waters Delta 600 with 600 Controller) with photodiode array detector (Waters 996) to quantify the amount of rutin and vitexin in the extract.

Figure 5(a) shows the chromatogram of AEPS. The retention times $\left(R_{t}\right)$ of the major peaks in the chromatogram of AEPS were compared with the $\mathrm{R}_{t}$ of rutin and vitexin. Peak $\mathrm{E}$ in the chromatogram $\left(\mathrm{R}_{t}=\right.$ $15.387 \mathrm{~min}$ ) corresponded to vitexin $\left(\mathrm{R}_{t}=15.382 \mathrm{~min}\right.$ ) (Figure $\left.5(\mathrm{~b})\right)$ while peak $\mathrm{F}\left(\mathrm{R}_{t}=17.449 \mathrm{~min}\right)$ corresponded to rutin $\left(\mathrm{R}_{t}=17.450 \mathrm{~min}\right)$ (Figure $5(\mathrm{~d})$ ). The sample was spiked with vitexin and rutin and the results confirmed the presence of vitexin (Figure 5(c)) and rutin (Figure 5(e)). Quantitative analysis of rutin and vitexin was carried out with reference to the standard curves of rutin $\left(\mathrm{y}=13487 \mathrm{x}-181561, \mathrm{r}^{2}=0.995\right)$ and vitexin $(\mathrm{y}=$ $\left.12313 \mathrm{x}-18598, \mathrm{r}^{2}=0.998\right)$. The concentration of vitexin in AEPS was $51.93 \pm 0.55 \mathrm{ppm}(0.5193 \%)$ while the concentration of rutin was $75.70 \pm 0.50 \mathrm{ppm}(0.7570 \%)$.

\subsection{Animals and experimental design}

The study was approved by the Animal Ethics Committee, Universiti Kebangsaan Malaysia (Approval Number: FP/FISIO/2015/ZAITON/11-FEB./639-FEB.-2015-SEPT. -2016) and was carried out in adherence to the Guidelines of Care and Use of Laboratory Animals, The National Academic Press. A total of 30 male Sprague Dawley (SD) rats, aged between 8 to 12 weeks old, were obtained from Animal Unit, Universiti Kebangsaan Malaysia, Kuala Lumpur. Rats were housed in plastic cages at constant laboratory temperature $\left(22 \pm 3^{\circ} \mathrm{C}\right)$ and maintained under 12:12 hours light: dark cycle throughout the experiment. Rats were fed with pellet and given water ad libitum. The animals were acclimatized for one week under the standard conditions before performing any experimental procedure.

The rats were then randomly allocated into five groups in which each group consists of six rats $(n=6)$. Rats in group 1 (control) received normal saline orally, whereas rats in group 2 received AEPS (500 $\mathrm{mg} / \mathrm{kg} /$ day) orally. Dex $(20 \mu \mathrm{g} / \mathrm{kg} /$ day) (Cayman Chemical, USA) was injected subcutaneously (s.c) to induce hypertension in groups 3, 4 and 5. Group 4 received concomitant Dex and AEPS (500 mg/ $\mathrm{kg} / \mathrm{day})$ while group 5 received concomitant Dex and captopril $(40 \mathrm{mg} / \mathrm{kg} /$ day given orally) (Cayman Chemical, USA). All the treatments were given for a total of 28 days.

The dose of dexamethasone $(20 \mu \mathrm{g} / \mathrm{kg} /$ day) was chosen as it had been shown to induce hypertension in rats [16]. The dose and treatment duration for AEPS $(500 \mathrm{mg} / \mathrm{kg} /$ day for 28 days) were adopted from previous studies which showed that AEPS at similar dose and treatment duration successfully reduced BP and increased NO in spontaneously hypertensive and L-NAME-induced hypertensive rats [12, 23]. 
Rats were sacrificed on day 29 using zoletil and xylazine (Virbac, France). The blood samples were collected using cardiac puncture. Thoracic aortae were dissected and cleaned off the surrounding connective tissues prior to homogenization for further tests.
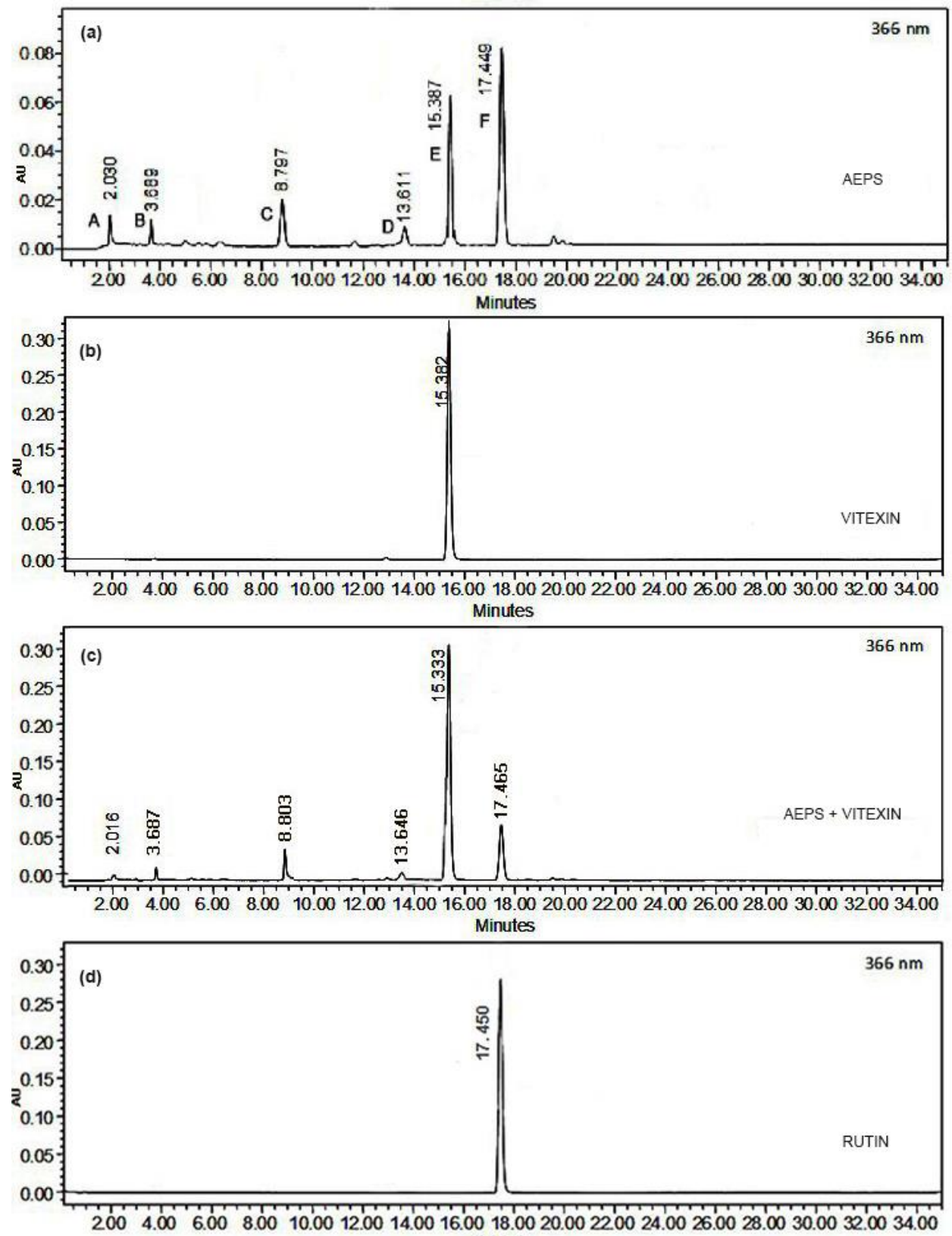
Minutes

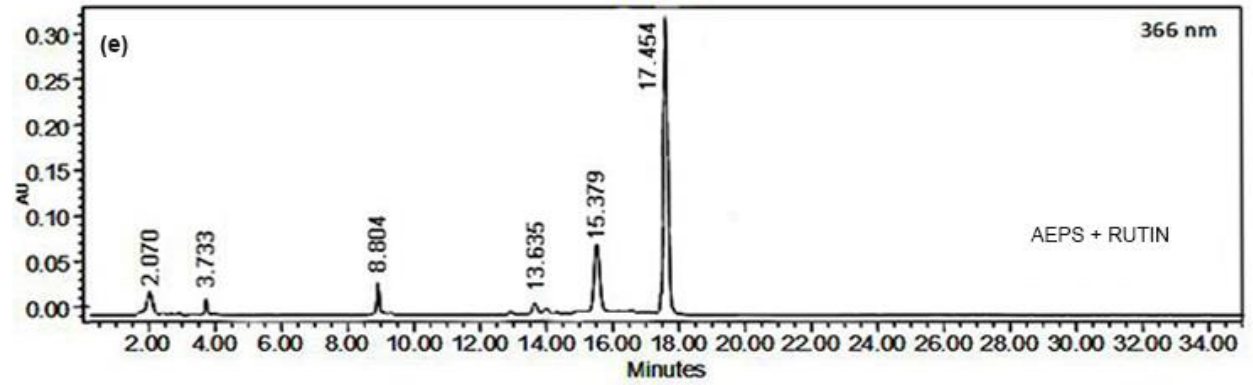

Figure 5. HPLC chromatograms of (a) aqueous extract of Piper sarmentosum (AEPS) (b) vitexin (c) AEPS + vitexin (d) rutin and (e) AEPS + rutin. 


\subsection{Measurement of blood pressure}

Systolic and diastolic blood pressure in conscious, restrained rats were measured at baseline (day 0), day 14 and day 28 using CODA ${ }^{\mathrm{TM}}$ non-invasive tail cuff system (Kent Scientific Corporation, USA). The interval of blood pressure measurements every fortnight was adopted from previous studies [12, 23]. The rats were placed on a heated chambers at $37^{\circ} \mathrm{C}$ during the measurement. At least five readings were recorded for each rat. The highest and the lowest readings were manually discarded and the average of the remaining three readings were taken as the blood pressure value [23].

\subsection{Determination of eNOS mRNA expression}

Total RNA was extracted from thoracic aorta samples using TRI reagent (MRC, USA) as described previously [24]. cDNA synthesis was carried out using SuperScript ${ }^{\circledR}$ Green Master Mix (ThermoFisher Scientific, USA). eNOS mRNA expression in the samples was measured using quantitative real time reverse transcriptase polymerase chain reaction (qPCR). Table 2 shows the primer sequence used in the reaction. Glyceraldehyde-3-phosphate dehydrogenase (GAPDH) was used as the control gene. The reaction was conducted using the thermocycling conditions as follows: initial denaturation at $95^{\circ} \mathrm{C}$ for 3 minutes, followed by 40 cycles of amplification at $95^{\circ} \mathrm{C}$ for $10 \mathrm{~s}$, annealing at $58^{\circ} \mathrm{C}$ for 30 seconds and extension at $72{ }^{\circ} \mathrm{C}$ for a minute. Each sample was run in duplicates. The specificity of the PCR reactions was verified by melting curve analysis and $0.8 \%$ agarose gel electrophoresis. mRNA expression of eNOS was calculated based on the threshold cycle (CT) value through the formula $2^{-\Delta \Delta C T}$, whereby $\Delta \Delta C T=C T$ GAPDH - CT eNOS [24].

Table 2. Primers used in $\mathrm{qPCR}$ analysis.

\begin{tabular}{ccccc}
\hline Gene & NCBI number & Primer Sequence (5' to 3') & $\begin{array}{c}\text { Product } \\
\text { Size } \mathbf{( b p )}\end{array}$ \\
\hline GAPDH & NM_017008.4 & $\begin{array}{c}\text { Forward } \\
\text { Reverse }\end{array}$ & $\begin{array}{l}\text { GTTACCAGGGCTGCCTTCTC } \\
\text { GATGGTGATGGGTTTCCCGT }\end{array}$ & 177 \\
eNOS & NM_021838.2 & $\begin{array}{c}\text { Forward } \\
\text { Reverse }\end{array}$ & $\begin{array}{c}\text { AGCGGCTGGTACATGAGTTC } \\
\text { CCGGGTGTCTAGATCCATGC }\end{array}$ & 105 \\
\hline
\end{tabular}

\subsection{Determination of eNOS protein level}

eNOS protein level in the thoracic aorta tissues was determined using enzyme-linked immunosorbent assay (ELISA) kit for rat's nitric oxide synthase 3 (USCN Life Science Inc, USA) according to the manufacturer's protocol. Aortic tissues were homogenized in $10 \mathrm{ml}$ of phosphate buffered saline (PBS), centrifuged at $5000 \mathrm{~g}$ for 5 minutes and the supernatant was collected. Samples were incubated in a 96-well plate containing biotinconjugated antibody specific to eNOS. After washing, the horseradish peroxidase-conjugated avidin was added followed by tetramethylbenzidine substrate solution. Optical densities (OD) of the wells were quantified at $450 \mathrm{~nm}$ using spectrophotometer. Total protein concentration in the samples was determined using Bradford method [25]. eNOS protein level was expressed as $\mathrm{pg} / \mathrm{mg}$ of total protein.

\subsection{Determination of eNOS activity}

EnzyChrome ${ }^{\mathrm{TM}}$ Nitric Oxide Synthase Assay kit (Bioassay System, USA) was used to determine eNOS activity. The principle of this assay was based on the measurement of nitrite produced by eNOS in the sample in a timed reaction. Aortic tissues were homogenized, centrifuged and the supernatant was collected as samples. The samples were then incubated for 20 minutes at $37^{\circ} \mathrm{C}$ in a buffer containing eNOS cofactor (tetrahydrobiopterin) and substrate (L-arginine). Each sample was tested in triplicates. The reaction mixture was centrifuged at $14000 \mathrm{~g}$ for 10 minutes and the supernatant was mixed with Griess reagents (sulfanilamide and N-(1-Naphthyl)ethylenediamine dihydrochloride). Total nitrite was measured at $540 \mathrm{~nm}$. Protein concentration in the samples was determined using Bradford method [25]. eNOS activity was expressed as $\mathrm{mM}$ nitrite $/ \mathrm{min} / \mathrm{mg}$ protein.

\subsection{Determination of NO level}

Serum NO concentration was measured using QuantiChrom ${ }^{\mathrm{TM}}$ Nitric Oxide Assay kit (Bioassay System, USA) following the manufacturer's protocol. Samples were mixed with Griess reagents (sulfanilamide and N(1-Naphthyl) ethylenediamine dihydrochloride). Subsequently, vanadium solution was added to the wells to allow reduction of nitrate to nitrite and the absorbance was measured at $540 \mathrm{~nm}$. 


\subsection{Statistical analysis}

Statistical analyses were performed using SPSS version 22.0 software. Data were tested for normality using Shapiro-Wilk test and analysed using two-way analysis of variance (ANOVA) and post hoc Tukey test. All the data were expressed as mean \pm S.E.M. Value of $P<0.05$ was considered to be statistically significant.

Acknowledgements: This research was funded by Universiti Kebangsaan Malaysia Medical Centre Fundamental Grant (FF-2017-040). We would like to thank Mr. Roger Davies for proof reading this paper.

Author contributions: Concept - A.U., A.A., A.A.H.; Design - A.U., A.A., A.A.H.; Supervision - A.U., A.A.; Resources - A.U., A.A., A.A.H., Z.A.; Materials - A.U., A.A., A.A.H., Z.A.; Data Collection and/or Processing - N.F.M.F., Z.A.; Analysis and/or Interpretation - N.F.M.F., A.U.; Literature Search - N.F.M.F., A.U.; Writing - N.F.M.F., A.U.; Critical Reviews - A.U., A.A., A.A.H., N.F.M.F., Z.A.

Conflict of interest statement: The authors declared no conflict of interest.

Ethics committee approval: The study was approved by the Animal Ethics Committee, Universiti Kebangsaan Malaysia (Approval Number: FP/FISIO/2015/ZAITON/11-FEB./639-FEB.-2015-SEPT. -2016)

\section{REFERENCES}

[1] Forouzanfar MH, Liu P, Roth GA, Ng M, Biryukov S, Marczak L, Alexander L, Estep K, Hassen Abate K, Akinyemiju TF, Ali R, Alvis-Guzman N, Azzopardi P, Banerjee A, Bärnighausen T, Basu A, Bekele T, Bennett DA, Biadgilign S, Catalá-López F, Feigin VL, Fernandes JC, Fischer F, Gebru AA, Gona P, Gupta R, Hankey GJ, Jonas JB, Judd SE, Khang YH, Khosravi A, Kim YJ, Kimokoti RW, Kokubo Y, Kolte D, Lopez A, Lotufo PA, Malekzadeh R, Melaku YA, Mensah GA, Misganaw A, Mokdad AH, Moran AE, Nawaz H, Neal B, Ngalesoni FN, Ohkubo T, Pourmalek F, Rafay A, Rai RK, Rojas-Rueda D, Sampson UK, Santos IS43, Sawhney M, Schutte AE, Sepanlou SG, Shifa GT, Shiue I, Tedla BA, Thrift AG, Tonelli M, Truelsen T, Tsilimparis N, Ukwaja KN, Uthman OA, Vasankari T, Venketasubramanian N, Vlassov VV, Vos T, Westerman R, Yan LL, Yano Y, Yonemoto N, Zaki ME, Murray CJ. Global Burden of Hypertension and Systolic Blood Pressure of at Least 110 to 115 mm Hg, 1990-2015. JAMA. 2017; 317(2): 165-182. [CrossRef]

[2] Mills KT, Bundy JD, Kelly TN, Reed JE, Kearney PM, Reynolds K, Chen J, He J. Global disparities of hypertension prevalence and control: a systematic analysis of population-based studies from 90 countries. Circulation. 2016; 134(6): 441-450. [CrossRef]

[3] Tomeleri CM, Marcori AJ, Ribeiro AS, Gerage AM, de Souza Padilha C, Schiavoni D, Souza MF, Mayhew JL, do Nascimento MA, Venturini D, Barbosa DS. Chronic blood pressure reductions and increments in plasma nitric oxide bioavailability. Int J Sports Med. 2017; 38(04): 290-299. [CrossRef]

[4] Li Q, Youn JY, Cai H. Mechanisms and consequences of endothelial nitric oxide synthase dysfunction in hypertension. J Hypertens. 2015; 33(6): 1128-1136. [CrossRef]

[5] Lu Y, Liu H, Bi Y, Yang H, Li Y, Wang J, Zhang Z, Wang Y, Li C, Jia A, Han L, Hu Y, Zhao Y, Wang R, Liu G. Glucocorticoid receptor promotes the function of myeloid-derived suppressor cells by suppressing HIF1 $\alpha$-dependent glycolysis. Cell Mol Immunol. 2018; 15(6): 618-629. [CrossRef]

[6] Reber LL, Daubeuf F, Plantinga M, De Cauwer L, Gerlo S, Waelput W, Van Calenbergh S, Tavernier J, Haegeman G, Lambrecht BN, Frossard N, De Bosscher K. A dissociated glucocorticoid receptor modulator reduces airway hyperresponsiveness and inflammation in a mouse model of asthma. J Immunol. 2012; 188(7): 3478-3487. [CrossRef]

[7] Soto-Piña AE, Franklin C, Rani CSS, Gottlieb H, Hinojosa-Laborde C, Strong R. A novel model of dexamethasoneinduced hypertension: use in investigating the role of tyrosine hydroxylase. J Pharmacol Exp Ther. 2016; 358(3): 528536. [CrossRef]

[8] Schäfer SC, Wallerath T, Closs EI, Schmidt C, Schwarz PM, Förstermann U, Lehr H. Dexamethasone suppresses eNOS and CAT-1 and induces oxidative stress in mouse resistance arterioles. Am J Physiol Heart Circ Physiol. 2005; 288(1): H436-444. [CrossRef]

[9] Thent ZC, Das S. Piper sarmentosum maintains blood pressure and morphological integrity of liver in type 1 diabetic rats. Int J Pharrma Med Biol Sci. 2015; 4: 24-28.

[10] Ab Rahman MR, Abdul Razak F, Mohd Bakri M. Evaluation of wound closure activity of nigella sativa, melastoma malabathricum, pluchea indica, and piper sarmentosum extracts on scratched monolayer of human gingival fibroblasts. Evid Based Complement Alternat Med. 2015;2014: 190342. [CrossRef] 
[11] Mohd Zainudin M, Zakaria Z, Megat Mohd Nordin NA, MM, Anita N, Othman F. Does oral ingestion of Piper sarmentosum cause toxicity in experimental animals? Evid Based Complement Alternat Med. 2013; 2013: 705950. [CrossRef]

[12] Mohd Zainuddin M, Zakaria Z, Megat Mohd Nordin NA. The use of Piper sarmentosum leaves aqueous extract $\left(K^{2}\right.$ adukmy $\left.{ }^{\mathrm{TM}}\right)$ as antihypertensive agent in spontaneous hypertensive rats. BMC Complement Altern Med. 2015; 10;15: 54. [CrossRef]

[13] Amran AA, Zakaria Z, Othman F, Das S, Raj S, Nordin NA. Aqueous extract of Piper sarmentosum decreases atherosclerotic lesions in high cholesterolemic experimental rabbits. Lipids Health Dis. 2010; 9(1): 44. [CrossRef]

[14] Luangpirom AK, Kourchampa W, Somsapt. P. Evaluation of hypoglycemic properties and fertility effect of Piper sarmentosum Roxb. aqueous leaf extract in streptozotocin induced diabetic mice. Int J Phytomed. 2014; 6(3): 448-454.

[15] Ugusman A, Zakaria Z, Hui CK, Nordin NA. Piper sarmentosum increases nitric oxide production in oxidative stress: a study on human umbilical vein endothelial cells. Clinics (Sao Paulo). 2010; 65(7): 709-714. [CrossRef]

[16] Ong SLH, Zhang Y, Sutton M, Whitworth JA. Hemodynamics of dexamethasone-induced hypertension in the rat. Hypertensi Res. 2009; 32(10): 889. [CrossRef]

[17] Wallerath T, Witte K, Schafer SC, Schwarz PM, Prellwitz W, Wohlfart P, Kleinert H, Lehr HA, Lemmer B, Förstermann U. Down-regulation of the expression of endothelial no synthase is likely to contribute to glucocorticoid-mediated hypertension. Proc Natl Acad Sci USA. 1999; 96(23): 13357-13362. [CrossRef]

[18] Tobias S, Habermeier A, Siuda D, Reifenberg G, Xia N, Closs EI, Förstermann U, Li H. Dexamethasone, tetrahydrobiopterin and uncoupling of endothelial nitric oxide synthase. J Geriatr Cardiol. 2015; 12(5): 528-539. [CrossRef]

[19] Ugusman A, Zakaria Z, Chua KH, Nordin NA, Abdullah Mahdy Z. Role of rutin on nitric oxide synthesis in human umbilical vein endothelial cells. ScientificWorldJournal. 2014; 2014: 169370. [CrossRef]

[20] Olaleye MT, Crown OO, Akinmoladun AC, Akindahunsi AA. Rutin and quercetin show qreater efficacy than nifedipin in ameliorating hemodynamic, redox, and metabolite imbalances in sodium chloride-induced hypertensive rats. Hum Exp Toxicol. 2014; 33(6): 602-608. [CrossRef]

[21] Maneesai P, Prasarttong P, Bunbupha S, Kukongviriyapan U, Kukongviriyapan V, Tangsucharit P, Prachaney P, Pakdeechote P. Synergistic antihypertensive effect of Carthamus tinctorius L. extract and Captopril in L-NAMEinduced hypertensive rats via rRestoration of eNOS and AT(1)R expression. Nutrients. 2016; 8(3): 122. [CrossRef]

[22] Ugusman A, Zakaria Z, Hui CK, Nordin NA, Mahdy ZA. Flavonoids of Piper sarmentosum and its cytoprotective effects against oxidative stress. Excli J. 2012; 11: 705-714.

[23] Alwi NA, Zakaria Z, Karim AA, Nordin NA, Ugusman A. Antihypertensive effect of Piper sarmentosum in LNAME-Induced hypertensive rats. SAINS MALAYS. 2018; 47(10): 2421-2428. [CrossRef]

[24] Ugusman A, Zakaria Z, Hui CK, Nordin NA. Piper sarmentosum inhibits ICAM-1 and Nox4 gene expression in oxidative stress-induced human umbilical vein endothelial cells. BMC Complement Altern Med. 2011; 11:31. [CrossRef]

[25] Valipour Nouroozi R, Valipour Noroozi M, Ahmadizadeh M. Determination of protein concentration using bradford microplate protein quantification assay. Int Elec J Med. 2015; 4(1): 11-17. [CrossRef]

This is an open access article which is publicly available on our journal's website under Institutional Repository at http://dspace.marmara.edu.tr. 